\title{
Reversion of Bacillus subtilis Protoplasts to the Bacillary Form Induced by Exogenous Cell Wall, Bacteria and by Growth in Membrane Filters
}

\author{
By D. CLIVE AND O. E. LANDMAN \\ Department of Biology, Georgetown University, Washington, D.C. 20007 , U.S.A.
}

(Accepted for publication 22 January 1970)

\begin{abstract}
SUMMARY
Methods were developed for growing protoplasts or $\mathbf{L}$ bodies of Bacillus subtilis into L colonies on membrane filters. Only some types of filters permitted growth; for optimum growth the filters usually had to be extracted with $2 \%(\mathrm{v} / \mathrm{v})$ ethanol in water. Scoring was greatly improved by staining. Growth on the filters induced reversion of the protoplasts to the bacillary form. Reversion was greatly enhanced when $B$. subtilis wall was added to the filter. A lesser enhancement occurred when wall was added to protoplasts growing in agar. The stimulation of reversion by wall was non-specific since similar stimulation could be obtained by intact autoclaved $B$. subtilis, Escherichia coli, pseudomonads and yeast. Stimulation of reversion probably depended on physical contact between the naked protoplasts or L bodies and the surface provided by the filter, wall, or killed organism. The present status of induced reversion in $B$. subtilis is discussed.
\end{abstract}

\section{INTRODUCTION}

Bacteria usually synthesize cell wall at a rate commensurate with the increase in cytoplasmic mass. Partial removal of the wall through enzyme action, or through growth in presence of inhibitors, presents only a temporary challenge to these cells. Thus, spheroplasts of Gram-negative species and the 'reverting' L forms obtained through multiplication of such spheroplasts (these morphologically mostly exhibit ' 3 B' forms; see Dienes \& Weinberger, I95I) promptly synthesize more wall as soon as lysozyme, or the inhibitory antibiotic, is removed (Landman, Altenbern \& Ginoza, 1958; Lederberg \& St Clair, 1958; Altenbern, 1963). Similarly, 'quasi-spheroplasts' of Bacillus subtilis, produced by partial removal of the wall by lysozyme, can apparently repair wall without difficulty (Miller, Zsigray \& Landman, I967; reviewed, Landman, 1968).

A sharply different situation is encountered when all the wall is removed: naked protoplasts, or $\mathrm{L}$ forms derived from them, are generally unable to re-initiate formation of new wall, especially in liquid media. On soft agar plates these wall-less forms give rise to $\mathrm{L}$ colonies consisting of irregularly-sized and -shaped, wall-less $\mathrm{L}$ bodies. Such L colonies have been called 'stable L colonies' to emphasize the heritably stable persistence of the wall-less state (Landman \& Halle, I963).

Protoplasts of Bacillus subtilis, or 'stable' L forms derived from such protoplasts can, however, be induced to initiate wall formation-i.e. to revert to the bacillary form-in media possessing special physical characteristics. Detailed studies of reversion 
in $B$. subtilis induced by $25 \%$ gelatin media have been published (Landman, Ryter \& Fréhel, 1968; Miller, Wiebe \& Landman, 1968; Landman \& Forman, 1969). An account of the induction of reversion by hard agar was given by Landman \& Halle (I963). Induction of reversion by membrane filters has also been mentioned (Landman, 1968).

Despite the fact that the $\mathrm{L}$ state is passed on heritably from one cell generation to the next, no loss or gain of nucleic acid-borne genetic information occurs during commitment to the $\mathrm{L}$ state or during reversion. This conclusion is implicit in the fact that each of these processes can occur in I hr with about $100 \%$ efficiency (Landman \& Halle, 1963; Landman \& Forman, 1969). Instead, it has been postulated that the heritable persistence of the $L$ state is due to the interruption of a feedback system which, in normal organisms, is responsible for the continuity of wall biosynthesis. According to this view, reversion of protoplasts or 'stable' $L$ forms entails a special priming process which triggers re-initiation of wall biosynthesis in these wall-less forms (McQuillen, 1956; Landman \& Halle, I963; Martin, 1963; Landman, I968).

In gelatin medium, reversion requires an initial period of protein synthesis (Landman \& Forman, 1969). This is followed by rapid deposition of a thin, apparently uniform, wall layer which then gradually thickens. Early during the wall deposition period, physical disturbance of the system by $3 \mathrm{~min}$. of warming (enough to melt the gelatin) markedly retards reversion (Landman et al. 1968). This observation points to a requirement for a solid gelatin barrier in close proximity to the organism. Furthermore, the evidence indicates that this barrier is required at the time when priming of wall synthesis occurs. The presence of a solid physical structure very near the membrane seems to be the sole feature common to all the reversion-stimulation environments: solid gelatin, hard agar and membrane filters. Such a barrier is present during wall synthesis in partially and normally walled organisms in the form of pre-existing wall. The work reported in this paper was initiated to investigate more closely the nature of this requirement for a physical barrier. Was direct contact between organisms and the barrier necessary? Would a barrier closely resembling Bacillus subtilis wall be more effective than a barrier of very different chemical constitution? Our experiments show that direct contact between the protoplasts and the surface is important, if not essential, and that wall preparations from $B$. subtilis are effective at inducing reversion, but that the effect is probably non-specific since preparations of wall material from other species are also effective.

\section{METHODS}

Microbial strains. In all experiments but one, Bacillus subtilis strain I68 (tryptophanrequiring) was used. The other organisms used are listed in Table 4.

Membrane filters. The various types of filters used are shown in Tables I and 2.

Extraction of inhibitory material from membrane filters. Three stacks of ten $4.7 \mathrm{~cm}$. filters, separated by Gelman type E glass fibre filters, were extracted in $5^{\circ} \mathrm{o} \mathrm{cm}$. diameter Soxhlet extraction thimbles (Kimax). The stack of filters was weighted down with a $4.5 \mathrm{~cm}$. diameter, $4 \mathrm{~cm}$. tall glass cylinder. After $4 \mathrm{hr}$ extraction with $750 \mathrm{ml} .2 \%(\mathrm{v} / \mathrm{v})$ ethanol in water, followed by $4 \mathrm{hr}$ extraction with distilled water, the filters were dried between paper towels. Weights were placed on the paper towels to prevent wrinkling. The dried filters were then sterilized by 10 min. exposure of each side to a General Electric G I5 T8 is W u.v. lamp at a distance of $30 \mathrm{~cm}$. 
Media. Most media were slightly modified versions of those used by Landman \& Halle (1963).

SS plating medium. $530 \mathrm{ml}$. distilled, de-ionized water containing $7.5 \mathrm{~g}$. Noble agar (Difco) and $\mathrm{I} \cdot \mathrm{O}$ g. $\mathrm{NH}_{4} \mathrm{NO}_{3}$ was brought to the boil and poured over $20 \mathrm{~g}$. Purified

\section{Table I. Viability and reversion of wall-less forms of B. subtilis on membrane filters of various characteristics}

\begin{tabular}{|c|c|c|c|c|c|c|c|c|}
\hline \multirow[b]{2}{*}{ Manufacturer } & \multirow[b]{2}{*}{ Type } & \multirow{2}{*}{$\begin{array}{l}\text { Chemical } \\
\text { composition }\end{array}$} & \multirow{2}{*}{$\begin{array}{l}\text { Pore } \\
\text { size } \\
(\mu)\end{array}$} & \multirow[b]{2}{*}{ Extracted } & \multirow[b]{2}{*}{ Side up } & \multicolumn{2}{|c|}{ Viability* } & \multirow{2}{*}{$\begin{array}{c}\text { Revertants } \\
\text { (P-inoculum) } \\
(\%)\end{array}$} \\
\hline & & & & & & $\mathrm{L}$ & $\mathbf{P}$ & \\
\hline $\begin{array}{l}\text { Schleicher \& } \\
\text { Schuell }\end{array}$ & B-6 & Nitrocellulose & 0.45 & $\begin{array}{l}- \\
\overline{+} \\
+\end{array}$ & $\begin{array}{l}\text { Concave } \\
\text { Convex } \\
\text { Concave } \\
\text { Convex }\end{array}$ & $\begin{array}{l}4 \\
4 \\
-\end{array}$ & $\begin{array}{l}2 \\
2 \\
4 \\
5\end{array}$ & $\begin{array}{l}- \\
40 \\
30\end{array}$ \\
\hline Millipore & HA & $\begin{array}{l}\text { Cellulose- } \\
\text { mixed esters }\end{array}$ & 0.45 & $\begin{array}{l}- \\
- \\
+ \\
+\end{array}$ & $\begin{array}{l}\text { Gridded } \\
\text { Plain } \\
\text { Gridded } \\
\text { Plain }\end{array}$ & $\begin{array}{r}4 \\
4 \\
-\end{array}$ & $\begin{array}{l}4 \\
5 \\
5 \\
5\end{array}$ & $\begin{array}{l}20 \\
20 \\
20 \\
20\end{array}$ \\
\hline Oxoid & - & $\begin{array}{l}\text { Cellulose-- } \\
\text { acetate }\end{array}$ & 0.45 & $\begin{array}{l}- \\
\bar{t} \\
+\end{array}$ & $\begin{array}{l}\text { Gridded } \\
\text { Plain } \\
\text { Gridded } \\
\text { Plain }\end{array}$ & $\begin{array}{r}3 \\
3 \\
- \\
-\end{array}$ & $\begin{array}{l}\text { I } \\
\text { I } \\
5 \\
5\end{array}$ & $\begin{array}{l}- \\
\text { 10 } \\
\text { 10 }\end{array}$ \\
\hline Millipore & AA & $\begin{array}{l}\text { Cellulose- } \\
\text { mixed esters }\end{array}$ & 0.80 & $\begin{array}{l}- \\
- \\
+ \\
+\end{array}$ & $\begin{array}{l}\text { Gridded } \\
\text { Plain } \\
\text { Gridded } \\
\text { Plain }\end{array}$ & $\frac{2}{-}$ & $\begin{array}{l}0 \\
0 \\
I \\
0\end{array}$ & $\begin{array}{l}- \\
- \\
-\end{array}$ \\
\hline Millipore & DA & $\begin{array}{l}\text { Cellulose- } \\
\text { mixed esters }\end{array}$ & 0.65 & $\begin{array}{l}- \\
-\end{array}$ & $\begin{array}{l}\text { Gridded } \\
\text { Plain }\end{array}$ & $\begin{array}{l}3 \\
3\end{array}$ & - & - \\
\hline Gelman & GM-6 & $\begin{array}{r}\text { Cellulose-- } \\
\text { di-acetate }\end{array}$ & 0.45 & $\begin{array}{l}- \\
- \\
+ \\
+\end{array}$ & $\begin{array}{l}\text { A§ } \\
\text { B } \\
\text { A } \\
\text { B }\end{array}$ & $\begin{array}{l}0 \\
0 \\
- \\
-\end{array}$ & $\begin{array}{l}0 \\
0 \\
3 \\
0\end{array}$ & $\frac{-}{10}$ \\
\hline Gelman & GA-8 & $\underset{\text { tri-acetate }}{\text { Cellulose- }}$ & 0.20 & $\begin{array}{l}- \\
\overline{+} \\
+\end{array}$ & $\begin{array}{l}\text { Glossy } \\
\text { Dull } \\
\text { Glossy } \\
\text { Dull }\end{array}$ & $\begin{array}{l}0 \\
0 \\
- \\
-\end{array}$ & $\begin{array}{l}\text { I } \\
4 \\
3 \\
3\end{array}$ & $\begin{array}{l}- \\
10 \\
10 \\
10\end{array}$ \\
\hline Gelman & GA-6 & $\begin{array}{c}\text { Cellulose- } \\
\text { tri-acetate }\end{array}$ & 0.45 & $\begin{array}{l}- \\
\overline{+} \\
+\end{array}$ & $\begin{array}{l}\text { Gridded } \\
\text { Plain } \\
\text { Gridded } \\
\text { Plain }\end{array}$ & $\begin{array}{l}0 \\
0 \\
- \\
-\end{array}$ & $\begin{array}{l}0 \\
0 \\
I \\
I\end{array}$ & - \\
\hline
\end{tabular}

* The viability of either protoplast inocula or inocula of $L$ bodies on membrane filters was compared to viability of the same inoculum on the same medium without membrane filters. SA or SS medium was used and viable counts were the combined totals of $\mathrm{L}$ colony counts-the majority of coloniesand bacillary colony counts. Growth response is coded as follows: $5=80$ to $100 \%$ of controls; $4=50$ to $80 \% ; 3=20$ to $50 \% ; 2=10$ to $20 \% ; \mathrm{I}=\mathrm{I}$ to $10 \% ; 0=$ no $\mathrm{L}$ growth.

$\dagger$ Not done.

$\ddagger$ Much variation was noted between experiments, but not within experiments. Rounded off average values are shown only for filter types where viability exceeds $20 \%$. Reversion was scored on the third day following inoculation.

$\S$ Both sides of filters looked the same. Both sides were tested by cutting filters in two and turning one of the halves over.

Pigskin Gelatin (Eastman). When the gelatin was dissolved, this mixture was autoclaved for $\mathrm{I} 5 \mathrm{~min}$. at $\mathrm{I} 2 \mathrm{I}^{\circ}$ and cooled to about $52^{\circ}$. Sterile, pre-warmed concentrated stock solutions of various reagents were then mixed in gently, in the order listed, to 
give the indicated final concentrations in $\mathrm{I}$ l.: sodium succinate, $\mathrm{pH} 7.3$ to $0.5 \mathrm{M}$; $\mathrm{K}_{2} \mathrm{HPO}_{4}$ and $\mathrm{KH}_{2} \mathrm{PO}_{4}$ to 3.5 and $\mathrm{I} \cdot 5 \mathrm{~g}$./l., respectively; glucose to $2 \cdot 0 \mathrm{~g}$./l.; $\mathrm{MgSO}_{4}$ to $5 \times \mathrm{IO}^{-3} \mathrm{M}$ and L-tryptophan (Nutritional Biochemicals) to $0.02 \mathrm{~g} / \mathrm{l}$. Plates were poured to a thickness of about $6 \mathrm{~mm}$. and stacked in piles of 30 during pouring to minimize differences in gelling conditions. They were then dried at room temperature for 3 days and used without further storage.

\section{Table 2. Membrane filters incapable of supporting colony formation by plated wall-less forms}

All filters shown in this table were tested under the same set of conditions as the filters in Table 1. None supported L colony growth whether ethanol extracted or not.

\begin{tabular}{|c|c|c|c|}
\hline \multicolumn{2}{|c|}{ Membrane filter } & \multirow[b]{2}{*}{ Chemical composition } & \multirow[b]{2}{*}{ Pore size $(\mu)$} \\
\hline Manufacturer & Type & & \\
\hline Gelman & $\begin{array}{l}\text { GM-4 } \\
\text { VM-I } \\
\text { VM-4 } \\
\text { VM-Ioo } \\
\text { VNW-800 } \\
\text { Alpha } 6 \\
\text { Versapor } 6424 \\
\text { Versapor } 6429 \\
\text { Glass Fibre type E }\end{array}$ & $\begin{array}{l}\text { Cellulose di-acetate } \\
\text { Poly-vinylchloride } \\
\text { Poly-vinylchloride } \\
\text { Poly-vinylchloride } \\
\text { Nylon-poly-vinylchloride } \\
\text { Regenerated cellulose } \\
\text { Reinforced epoxy } \\
\text { Reinforced epoxy } \\
\text { Glass microfibres }\end{array}$ & $\begin{array}{l}0.80 \\
5.0 \\
0.80 \\
10.0 \\
0.80 \\
0.45 \\
5.0 \\
0.90 \\
?\end{array}$ \\
\hline Selas & $\begin{array}{l}\text { FM } 47 \\
\text { FM } 47 \\
\text { FM } 47\end{array}$ & $\begin{array}{l}\text { Silver } \\
\text { Silver } \\
\text { Silver }\end{array}$ & $\begin{array}{l}0.20 \\
0.45 \\
0.80\end{array}$ \\
\hline Millipore & $\begin{array}{l}\text { NC } \\
\text { NR } \\
\text { EH } \\
\text { VM } \\
\text { BC } \\
\text { RH }\end{array}$ & $\begin{array}{l}\text { Nylon } \\
\text { Nylon } \\
\text { Cellulose acetate } \\
\text { Cellulose-mixed esters } \\
\text { Information not available } \\
\text { Information not available }\end{array}$ & $\begin{array}{l}14 \cdot 0 \\
1 \cdot 0 \\
0.50 \\
0.05 \\
? \\
?\end{array}$ \\
\hline
\end{tabular}

Table 3. Some characteristics of the stimulation of reversion by exogenous wall

The crude wall preparation used in these experiments was a suspension in DF of a washed 1000 to $10,000 \mathrm{~g}$ fraction of sonicated Bacillus subtilis. All platings were done in triplicate.

Plating surface

Soft agar (SS medium)

Ethanol extracted membrane filter resting on SS medium
Inducer added Reversion

$\begin{array}{lr}\text { None } & \text { I } \\ \text { Unheated wall } & 4 \\ \text { Heated wall } & 8 \\ \text { None } & 4 \\ \text { Unheated wall } & 27 \\ \text { Heated wall } & 49\end{array}$

$S A$ plating medium. This medium was the same as SS medium except that $2 \mathrm{~g} . / 1$. bovine serum albumin (Fraction V, Armour) was substituted for the gelatin, the agar was $8 \mathrm{~g}$./1. Bacto Agar (Difco), and $5 \times 10^{-3} \mathrm{M}^{-} \mathrm{MgCl}_{2}$ was used instead of $\mathrm{MgSO}_{4}$. The serum albumin was filter-sterilized and added last.

TPM liquid medium. This medium was used for preparing protoplasts and was a modification of the SL 2 medium of Landman \& Halle (1963). The source of $\mathrm{Mg}^{2+}$ is 


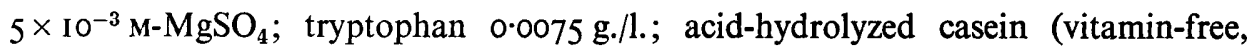
Difco) was $0.1 \mathrm{~g} . / 1$. and EDTA $5 \times 10^{-5} \mathrm{M}$.

DFC dilution fluid. This medium, used in dilution and plating of protoplasts and $\mathrm{L}$ bodies, contained: sodium succinate $(\mathrm{pH} 7 \cdot 3) 0.25 \mathrm{M}$; sucrose $0.25 \mathrm{M} ; \mathrm{K}_{2} \mathrm{HPO}_{4}$ 3.5 g./l.; $\mathrm{KH}_{2} \mathrm{PO}_{4} \mathrm{I} \cdot 5 \mathrm{~g}$./l.; $\mathrm{MgCl}_{2} 5 \times \mathrm{IO}^{-3} \mathrm{M}$; EDTA $\mathrm{IO}^{-4} \mathrm{M}$. Concentrated stock solutions were autoclaved separately and added to sterile distilled water in the order listed.

Preparation and handling of protoplast suspensions. The initial stages of protoplast preparation were as described by Landman \& Halle (1963). Organisms were shaken in SL I medium (Landman \& Halle, I963) for $4.5 \mathrm{hr}$ at $37^{\circ}$, diluted $\mathrm{r} / 9$ into TPM and shaken for another $\mathrm{I} \cdot 5 \mathrm{hr}$ at $37^{\circ}$. Then lysozyme was added to $300 \mu \mathrm{g}$. $/ \mathrm{ml}$., the cultures transferred to Erlenmeyer flasks in a water bath at $32^{\circ}$ and incubated in shallow layers without agitation for another $\mathrm{I} \cdot 5 \mathrm{hr}$. At this time formation of protoplasts was about $99.99 \%$ complete in that only about I cell in I $\mathrm{O}^{4}$ formed a bacillary colony on SS medium; the rest formed L colonies. Survival was between 60 and $100 \%: 60$ to I0o L colonies were formed for every 100 bacillary colonies formed by the original bacterial suspension. The organisms were centrifuged at $8000 \mathrm{~g}$ at room temperature for $12 \mathrm{~min}$., resuspended in DFC and centrifuged and washed 3 times more to remove lysozyme. The final resuspension was in one-tenth the original volume. Some loss of viability occurred: in an average experiment the viable count of the washed protoplast suspension was about $25 \%$ of that of the initial bacillary suspension. The washed protoplast suspension was dispensed in I ml. samples in test tubes, plunged into a dry-ice + acetone mixture for at least $10 \mathrm{~min}$. before storage in a deep freeze at $-20^{\circ}$. When melted immediately the viability had fallen to about $15 \%$ of the original count. During storage viability declined slowly to $5 \%$ of the original value in 2 months. For a series of experiments, a stock suspension of frozen protoplasts was prepared and samples of closely predictable viability withdrawn from storage for use.

Preparation of L-body suspensions. Protoplasts were inoculated on SS plates and incubated at $30^{\circ}$ for about $24 \mathrm{hr}$. Sterile DFC (O.I ml.) was then dispensed on each plate and the growth re-spread. This procedure was repeated on the second and third day after inoculation. Occasional contaminating bacillary colonies were carefully excised before re-spreading. Finally, the plates were incubated at $30^{\circ}$ for 2 more days. DFC ( $5 \mathrm{ml}$.) was added to the near-confluent growth of $L$ colonies so obtained and much of the growth was suspended in it by gentle rubbing with a spreader. This suspension was pipetted off, diluted and used within I hour.

Preparation of crude wall suspensions. Bacillus subtilis strain 168 trp- was grown overnight in Brain Heart Infusion (BHI, Difco), centrifuged, resuspended, and washed once in cold 0. I M-potassium phosphate buffer $\left(\mathrm{pH}_{5} \cdot \mathrm{O}^{\circ}\right.$ to decrease autolytic enzyme activity (Young, 1966). The suspension was then disrupted for 5 to 10 min. in a Branson Sonifier (Model S 75), at maximum settings; breakage was monitored by phasecontrast microscopy. The treated suspension was centrifuged for $15 \mathrm{~min}$. at $1000 \mathrm{~g}$, the pellet discarded, and the supernatant fluid centrifuged for $15 \mathrm{~min}$. at $10,000 \mathrm{~g}$. The pellet from this step was resuspended in cold o.I M-potassium phosphate buffer $\left(\mathrm{pH}^{\circ}{ }^{\circ}\right)$ and the cycle of centrifugation at $1000 \mathrm{~g}$ followed by $10,000 \mathrm{~g}$ was repeated twice to improve the homogeneity of the preparation. The final pellet was suspended in DFC and stored at $-20^{\circ}$ or below. Undiluted wall suspension ( $.1 \mathrm{ml}$.) was plated in each experiment and was always sterile. 
Preparation of heat-killed intact-organism suspensions. The various micro-organisms were grown in BHI to late exponential phase, autoclaved, and washed three times in sterile $0.85 \%(\mathrm{w} / \mathrm{v}) \mathrm{NaCl}$. The final pellet was resuspended in DFC, steamed at $100^{\circ}$ for 5 to 10 min., and then stored at $-20^{\circ}$ or below. Undiluted suspensions were plated in each experiment and were always sterile.

Standardization of suspensions for use in experiments on induction of reversion. Suspensions were adjusted to $10 \%$ transmission at $670 \mathrm{~m} \mu$ in the Bausch and Lomb Model 20 Spectrophotometer. About $66 \mu \mathrm{g}$. dry matter in $0.1 \mathrm{ml}$. was spread on a membrane filter or agar plate and allowed to dry. Then the protoplasts were inoculated on to the same surfaces.

Staining for visual differentiation of bacillary and $L$ colonies on membrane filters. A few drops of a I/I mixture of Loeffler's alkaline methylene blue (Pelczar, 1965) with a $0.25 \%$ solution of safranin in $10 \%$ ethanol were introduced beneath the filter. About $30 \mathrm{~min}$. later the colonies on the membrane filters were scored with a dissecting microscope.

\section{RESULTS}

\section{Viability and reversion on membrane filters}

Although previous experiments in our laboratory had shown that $\mathrm{L}$ forms could grow and revert on membrane filters, results were initially very variable. This situation has now been much improved because differential staining greatly improved scoring of $L$ colonies (see methods) and plating efficiency was often enhanced by the removal of inhibitors from the membrane filters through extraction with $2 \%(\mathrm{v} / \mathrm{v})$ ethanol in water (Cahn, 1967).

The growth of protoplast and $L$ form inocula was studied on extracted and on unextracted filters. About Ioo viable bodies were spread on filters resting on SA medium or, in the case of the controls, directly on SA medium. After 3 to 4 days at $30^{\circ}$ bacillary (B) and $\mathrm{L}$ colonies were counted. The two surfaces of the membrane filters did not always behave similarly (Tables I and 2) and only membrane filters made from substituted celluloses supported L growth. The effect of ethanol extraction was not predictable: with Oxoid and with Schleicher \& Schuell filters, extraction improved plating efficiency, whereas extraction had little effect on Millipore HA filters. Not all batches of filters of a given manufacture behaved identically and these differences persisted after extraction.

\section{The effect of exogenous wall on reversion}

The observation that growth and reversion of $\mathrm{L}$ colonies was restricted to filters made of polysaccharide material suggested that similarities between these filters and normal cell wall might be important. In the case of reversion, earlier observations implicated wall in the continued synthesis of more wall and in the re-initiation of new wall biosynthesis (Landman, 1968; Miller et al. 1967). A logical test of this view was, therefore, to attempt to stimulate reversion by added exogenous wall.

Wall preparation (O. I ml. containing $66 \mu \mathrm{g}$. dry wt in DFC) was spread directly on to extracted Schleicher \& Schuell B6 filters resting on SS medium or on to equivalent areas of SS medium. After drying, about 300 protoplasts suspended in DFC were spread on the inoculated surfaces and on to control filters and plates without wall. The plates were scored for $\mathrm{B}$ and $\mathrm{L}$ colonies following incubation at $30^{\circ}$ for 3 days 
(Table 3). Clearly, wall stimulated reversion considerably. Boiled wall was more effective than untreated wall, presumably because boiling inactivated an autolytic enzyme. Reversion occurred much more freely when the protoplasts were in contact with the wall on the membrane than in the agar environment, suggesting that a sustained and firm contact between reverting protoplasts and the stimulating wall fragments was necessary.

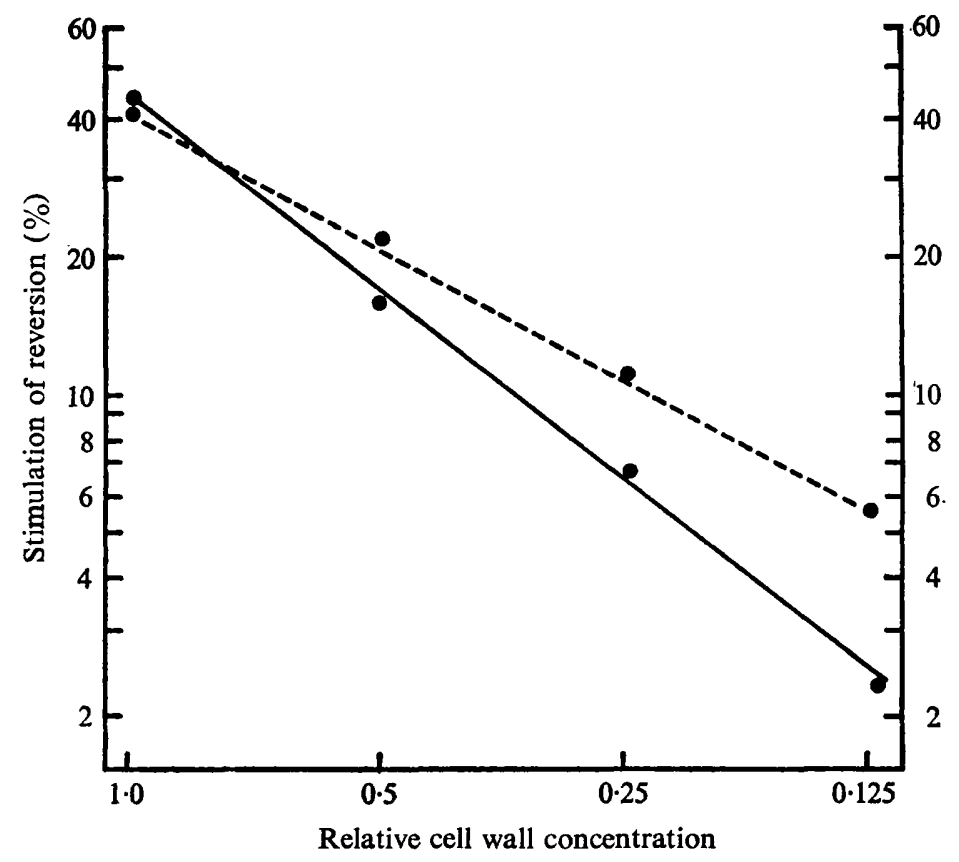

Fig. I. Relationship between wall concentration and reversion. Twofold serial dilutions of a Bacillus subtilis crude wall preparation were spread on to ethanol-extracted Schleicher \& Schuell B-6 membrane filters resting on SS medium. The greatest amount plated corresponded to the wall content of $5 \times 10^{8}$ whole cells. If spread in a single layer over the filter surface these walls would cover about $42 \%$ of the total surface area of the filter. The lower concentrations would cover proportionately smaller fractions of this area (broken line). About 500 protoplasts were spread on top of these preparations, the plates were incubated for 3 days at $30^{\circ}$ and then scored for $\mathrm{B}$ and $\mathrm{L}$ colonies. The percentage reversion figures shown (solid line) are corrected for background reversion ( $7 \cdot 1 \%)$ observed on membrane filters without added cell wall.

\section{The effect of wall concentration on reversion}

Serial dilutions (o.I ml.) of boiled wall suspension in DFC ( $660 \mu \mathrm{g}$. dry wt/ml.) were spread on membrane filters and dried. Protoplasts were added and the plates scored for $\mathrm{B}$ and $\mathrm{L}$ colonies after 3 days at $30^{\circ}$. Reversion appeared to be an exponential function of the concentration of added wall despite the fact that the wall of $10^{5} 1010^{8}$ organisms had to be added to obtain a single reversion (Fig. I). This result suggests that the physical wall itself rather than an associated diffusible product stimulated reversion. The approximate proportion of the filter surface covered by the added wall suspensions has been calculated and included in Fig. I; the similarity between the two curves is consistent with the hypothesis that physical contact between wall fragment and protoplast is required to trigger reversion. 
Reversion in the presence of heat-killed Bacillus subtilis. Time of appearance of revertant colonies

To avoid the time-consuming task of preparing wall fractions, we tested whether reversion could be induced by heat-killed bacilli. Autoclaved, washed Bacillus subtilis induced reversion with an efficiency comparable to a wall fragment preparation. Fig. 2 shows the time of appearance of revertants in this system. A suspension of killed cells in DFC ( $0.1 \mathrm{ml}$. containing $250 \mu \mathrm{g}$. dry wt) was spread on to extracted Millipore

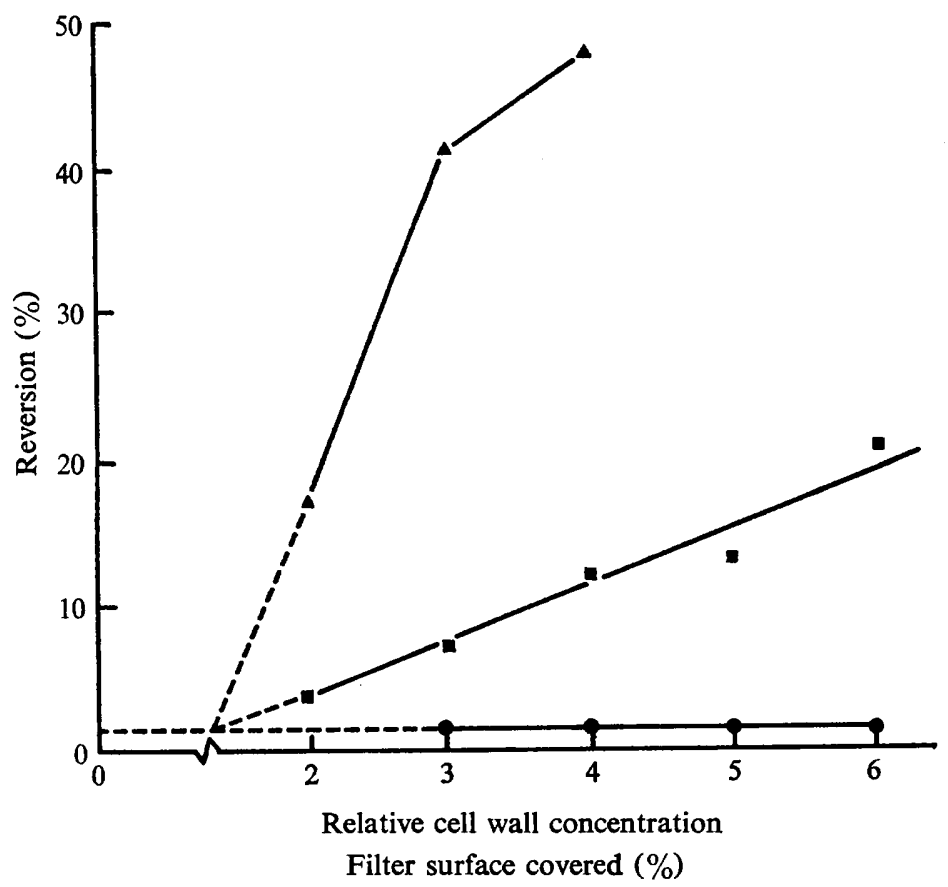

Fig. 2. Time course of the induction of reversion by killed, intact Bacillus subtilis and by membrane filters alone. About 500 protoplasts were spread on either SS plating medium alone (-), ethanol-extracted Millipore HA filters resting on SS medium ( $\square-\square)$, or extracted filters previously spread with $5 \times 10^{8}$ autoclaved $B$. subtilis, resting on SS medium $(\Delta-\Delta)$. The plates were incubated at $30^{\circ}$ and at the times indicated three randomly chosen plates from each group were counted, using a differential stain to distinguish reverted and non-reverted colonies.

HA filters, resting on SS medium. After drying, about 500 protoplasts were spread on the filters with or without killed cells, and also on plain SS medium. All plates were incubated at $30^{\circ}$ and a selection withdrawn and scored for B and L colonies after 2, 3, 4,5 and 6 days. Besides displaying marked stimulation by autoclaved bacilli Fig. 2 also shows that the time course of appearance of revertants was approximately linear on Millipore HA filters without killed bacilli. Since multiplication of $\mathrm{L}$ bodies and a consequent change in the area of surface contact between $L$ bodies and membrane filter occurred during much of the period, the apparent simplicity of these results may well be deceptive. 


\title{
Stimulation of reversion by other killed micro-organisms
}

Since heat-killed Bacillus subtilis and wall induced reversion, the question of specificity became important. Autoclaved suspensions of a wide range of Gram-positive and Gram-negative bacilli, Gram-positive cocci and yeast, all at about $2.5 \mathrm{mg}$. dry wt/ml., were compared with a suspension of $B$. subtilis of similar concentration. Table 4 shows clearly that reversion stimulated by autoclaved bacteria is non-specific; no matter what the chemical nature of their surface, all bacteria were about equally effective. Even killed yeast suspensions exerted a significant stimulatory effect, despite the fact that they suppressed about $50 \%$ of the $\mathrm{L}$ colony growth.

\section{Table 4. Stimulation of reversion by killed micro-organisms of various types}

\begin{abstract}
Cultures were grown overnight in Brain Heart Infusion medium, autoclaved, washed 3 times in sterile saline, resuspended in DFC to about $5 \times 10^{9}$ organisms $/ \mathrm{ml}$. and finally steamed for Io min. One-tenth $\mathrm{ml}$. samples were spread on Schleicher \& Schuell B-6 filters resting on SS medium and allowed to dry before about 500 Bacillus subtilis protoplasts were added. After 3 days at $30^{\circ}$ the plates were scored for B and L colonies. The stimulatory capacity of $B$. subtilis was taken as $\mathrm{I} \cdot \mathrm{O}$. Means and standard deviations of the relative stimulatory capacities were calculated from a minimum of 3 filters for each inducer.
\end{abstract}

\begin{tabular}{|c|c|c|}
\hline Organism & $\begin{array}{l}\text { Relative } \\
\text { stimulatory } \\
\text { capacity }\end{array}$ & $\begin{array}{l}\text { Standard } \\
\text { deviation }\end{array}$ \\
\hline Bacillus subtilis, strain $168 \operatorname{trp}^{-}$ & $\begin{array}{c}1 \cdot 0 \\
\text { (Reference)* }\end{array}$ & 0.2 \\
\hline B. cereus, strain $569 \mathrm{~S}^{r}$ & $\mathbf{I} \cdot \mathbf{2}$ & 0.4 \\
\hline B. megaterium, ATCC 9885 & $\mathbf{I} \cdot \mathbf{I}$ & 0.4 \\
\hline B. stearothermophilus, strain Schmidt & I.O & 0.3 \\
\hline Escherichia coli, АTCC I 1303 & $1 \cdot 3$ & 0.3 \\
\hline Proteus mirabilis, strain PMI (Baron) & $\mathbf{I} \cdot \mathbf{I}$ & 0.3 \\
\hline Salmonella typhimurium, strain I $334-57$ (CDC) & 0.9 & 0.1 \\
\hline Pseudomonas aeruginosa, ATCC I4216 & $\mathbf{I} \cdot \mathbf{I}$ & 0.0 \\
\hline Staphylococcus aureus, АТсC 6020 & $\mathbf{I} \cdot \mathbf{I}$ & 0.4 \\
\hline Saccharomyces cerevisiae, ATCC 9763 & 0.8 & 0.3 \\
\hline
\end{tabular}

\section{DISCUSSION}

Partial or complete removal of the wall generally deprives bacteria of their ability to septate (Altenbern \& Landman, I960; Lederberg \& St Clair, 1958). Accordingly, spheroplasts and protoplasts are unable to divide in liquid media. Only solid media possessing very special supporting properties can provide a substratum where these soft wall-deficient forms can continue to multiply as they 'ooze between and subdivide themselves among the fibres' (Landman \& Halle, I963). Among the standard bacteriological media, only soft agar is suitable, not hard agar or gelatin. Our present findings and earlier reports (Dienes, I968; Dienes \& Madoff, I966; Landman, 1968) show that some types of membrane filters can also support $\mathrm{L}$ colony growth. The fact that only a few of the filter types can provide the required substratum for multiplication is not surprising in the light of the results with standard bacteriological media: the finding that growth of $\mathrm{L}$ forms appears to be restricted to filters in a certain range of porosities (Tables I and 2) is quite analogous, for example, to the earlier observation that an increase in agar concentration can interdict $\mathrm{L}$ colony formation. 
By using filters of appropriate pore size, composition and manufacture, extracting with $2 \%(v / v)$ ethanol in water and scoring with the aid of the differential stain, a useful advance in the technology of use of membrane filters for the growth of $L$ colonies of Bacillus subtilis has been achieved.

Five types of environment have now been found to stimulate reversion of $B$. subtilis protoplasts or $\mathrm{L}$ bodies to the bacillary form: gelatin, hard agar, membrane filters, exogenous wall or heat-killed intact micro-organisms; to which should, perhaps, be added the residual endogenous wall of 'quasi-spheroplasts'. These reversion-inducing materials have little in common besides their particulate or solid state. In the case of washed membrane filters, it seems particularly clear that their ability to stimulate reversion must be due to the physical nature of the insoluble filter rather than to any soluble chemical constituent.

The effect of the chemical composition of the filters on reversion is less clear-cut. With cellulose filters, changes in the chemical substituents of the cellulose have little effect on their ability to induce reversion. The chemical nature of the non-cellulose based membranes may be much more important in the reversion process, but the lack of protoplast growth obtained with these filters precludes their investigation. In the exogenous microbial (or wall) system, the results are unambiguous: stimulation of reversion depends markedly on the amount of wall or killed microbial mass present and on firm contact between exogenous material and protoplasts (Table 3) and scarcely at all on the chemical constitution of the reversion-inducing organism surface.

Since the main factors affecting the growth of protoplasts on membranes are physical rather than chemical, we may now ask how these properties allow the re-initiation of wall synthesis. There are several possibilities which are not mutually exclusive. (i) The physical barrier near the membrane may slow diffusion of wall precursors or exoenzymes involved in wall synthesis, so that a priming quantity of cell wall can accumulate. (ii) The physical barrier may adsorb wall precursors and/or exoenzymes and thereby allow priming. In these instances, priming is regarded as the production of a wall polymer sufficiently large to permit its own further extension by the organism's normal wall-building system (as in a quasi-spheroplast). (iii) The barrier may adsorb, and thereby block the action of, a wall-destroying enzyme or repressor of wall biosynthesis. (iv) The barrier may induce, by an unknown mechanism, renewed formation of wall precursors whose synthesis has been repressed by removal of wall. This last possibility is underlined by the finding (Bond, 1969) that diaminopimelic acid production is profoundly depressed in protoplasts and $\mathrm{L}$ forms of $B$. subtilis.

While the research reported in this paper has helped us to eliminate some hypotheses, particularly those involving chemical priming, we cannot decide which of the foregoing possibilities, if any, is correct. Whatever the molecular events underlying reversion, the characteristics of all known reversion-inducing systems (hard agar, gelatin, partly walled 'quasi-sphero plasts', membrane filters, exogenous wall or autoclaved bacteria) suggest that, for a period early in the process, the naked cells must be kept in close, undisturbed physical contact with a solid substratum.

We gratefully acknowledge Predoctoral Fellowship awards to D. C. from the Institute for General Medical Sciences, N.I.H. no. 33993-OI and -02. This work was supported by successive Grants GB 4506 and GB 7204 from the National Science Foundation and by Grant AI 05972 from the National Institutes of Health. This work 
is taken from a Dissertation by D. C. submitted to Georgetown University in partial fulfilment of the requirements for the degree of Doctor of Philosophy. A partial summary is published in Bacteriological Proceedings 1968, p. 58.

\section{REFERENCES}

Altenbern, R. A. (1963). Reversion of L forms and spheroplasts of Proteus mirabilis. Journal of Bacteriology 85, 269.

Altenbern, R. A. \& Landman, O. E. (1960). Growth of L forms of Proteus mirabilis in liquid media. Journal of Bacteriology 79, 5 I0.

Bond, E. (1969). Gene activity following cell wall removal in the wild type and in a mutant of Bacillus subtilis capable of growth in liquid media in the L-form. Ph.D. Dissertation, Georgetown University.

CaHN, R. D. (1967). Detergents in membrane filters. Science, New York 155, 195.

DiENES, L. (1968). Morphology and reproductive processes of bacteria with defective cell wall. In Microbial Protoplasts, Spheroplasts and L-Forms, p. 74. Edited by L. B. Guze. Baltimore: Williams and Wilkins.

Dienes, L. \& MAdoff, S. (1966). Development and growth of L forms of bacteria and PPLO on membrane filters. Proceedings of the Society for Experimental Biology and Medicine 121, 334.

Dienes, L. \& WeInBerger, H. J. (195I). The L forms of bacteria. Bacteriological Review's 15, 245.

LANDMAN, O. E. (1968). Protoplasts, spheroplasts and $\mathrm{L}$ forms viewed as a genetic system. In Microbial Protoplasts, Spheroplasts and L-Forms, p. 319. Edited by L. B. Guze. Baltimore: Williams and Wilkins.

Landman, O. E., Altenbern, R. A. \& Ginoza, H. S. (1958). Quantitative conversion of cells and protoplasts of Proteus mirabilis and Escherichia coli to the L-form. Journal of Bacteriology 75, 567.

Landman, O. E. \& Forman, A. (1969). Gelatin-induced reversion of protoplasts of Bacillus subtilis to the bacillary form: Biosynthesis of macromolecules and wall during successive steps. Journal of Bacteriology 99, 576.

Landman, O. E. \& Halle, S. (1963). Enzymically and physically induced inheritance changes in Bacillus subtilis. Journal of Molecular Biology 7, $72 \mathrm{I}$.

Landman, O. E., Ryter, A. \& FréHel, C. (1968). Gelatin-induced reversion of protoplasts of Bacillus subtilis to the bacillary form: electron-microscopic and physical study. Journal of Bacteriology 96, 2154.

Lederberg, J. \& St Clair, J. (1958). Protoplasts and L-type growth of Escherichia coli. Journal of Bacteriology 75, 143 .

MCQuillen, K. (1956). Capabilities of bacterial protoplasts. Symposia of the Society for General Microbiology 6, 127.

MARTIN, H. H. (1963). Bacterial protoplasts-a review. Journal of Theoretical Biology 5, I.

Miller, I. L., Wiebe, W. \& LANDMAN, O. E. (I968). Gelatin-induced reversion of protoplasts of Bacillus subtilis to the bacillary form: photomicrographic study. Journal of Bacteriology 96, 2171 .

Miller, I. L., Zsigray, R. M. \& LANDMAN, O. E. (1967). The formation of protoplasts and quasispheroplasts in normal and chloramphenicol-pretreated Bacillus subtilis. Journal of General Microbiology 49, 513.

Pelczar, M. J., Jun. (1965). In Laboratory Exercises in Microbiology, 2nd ed., p. 339. New York: McGraw-Hill.

Young, F. E. (1966). Autolytic enzyme associated with cell walls of Bacillus subtilis. Journal of Biological Chemistry 24I, 3462. 